\title{
Contributions of epithelial-mesenchymal transition and cancer stem cells to the development of castration resistance of prostate cancer
}

Ping Li ${ }^{1}$, Ru Yang ${ }^{1 *}$ and Wei-Qiang Gao ${ }^{1,2^{*}}$

\begin{abstract}
An important clinical challenge in prostate cancer therapy is the inevitable transition from androgen-sensitive to castration-resistant and metastatic prostate cancer. Albeit the androgen receptor (AR) signaling axis has been targeted, the biological mechanism underlying the lethal event of androgen independence remains unclear. New emerging evidences indicate that epithelial-to-mesenchymal transition (EMT) and cancer stem cells (CSCs) play crucial roles during the development of castration-resistance and metastasis of prostate cancer. Notably, EMT may be a dynamic process. Castration can induce EMT that may enhance the stemness of CSCs, which in turn results in castration-resistance and metastasis. Reverse of EMT may attenuate the stemness of CSCs and inhibit castration-resistance and metastasis. These prospective approaches suggest that therapies target EMT and CSCS may cast a new light on the treatment of castration-resistant prostate cancer (CRPC) in the future. Here we review recent progress of EMT and CSCS in CRPC.
\end{abstract}

Keyword: Castration-resistant, Prostate cancer, Epithelial-to-mesenchymal transition, Cancer stem cells, Signaling pathways

\section{Introduction}

Prostate cancer is the leading cause of cancer incidence and the second leading cause of cancer-related deaths amongst males in the United States. Androgen deprivation therapy (ADT) remains the mainstay therapy for advanced prostate cancer in addition to surgery. Many studies have been focused on androgen/androgen receptor (AR) signaling axis. Drugs targeting AR pathway have been developed in the past several decades, including estrogens (such as diethylstilbestrol, a luteinizing hormone-releasing hormone inhibitor), steroidal anti-androgens (such as cyproterone acetate, megestrol acetate and medroxyprogesterone acetate) and nonsteroidal antiandrogens (such as flutamide, nilutamide and bicalutamide, androgen receptor blockers), and gonadotropin-releasing hormone $(\mathrm{GnRH})$ antagonists (such as abarelix and degarelix).

\footnotetext{
* Correspondence: yangru@yahoo.com; gao.weiqiang@sjtu.edu.cn ${ }^{1}$ State Key Laboratory of Oncogenes and Related Genes, Stem Cell Research Center, Renji Hospital, School of Medicine, Shanghai Jiao Tong University, Shanghai, China

${ }^{2}$ Med-X Research Institute, Shanghai Jiao Tong University, Shanghai, China
}

Although initially effective at regressing tumor growth, these androgen deprivation therapies will ultimately fail, rendering a lethal drug-resistant stage commonly known as castration-resistant prostate cancer (CRPC). The biological basis underlying the development of metastatic androgenindependent prostate cancer has been addressed, mainly focusing on AR over-expression, mutation, and cross-talk to other growth factor signaling pathways [1]. Due to recognition of continued AR signaling in the progress of CRPC, several new drugs include MDV3100, abiraterone acetate and VN-124-1 have been investigated in clinical trials, and the former two drugs have been approved by US Food and Drug Administration last year. However, the potential mechanisms by which prostate cancer cells become CRPC still remain largely unclear.

In recent years, accumulating evidences indicate that epithelial-to-mesenchymal transition (EMT) and cancer stem cells (CSCs) play important roles during the development of drug resistance of prostate cancer. Unveiling the molecular mechanisms responsible for EMT and CSCs would help to develop new promising therapies for metastatic prostate cancer in the future. In this review, we will 
summarize our current understanding regarding EMT and CSCs in CRPC, including possible relationships between EMT and CSCs and specific signaling pathways involved during generation of EMT and CSCs (Figure 1).

\section{Epithelial-to-mesenchymal transition and castration-resistant prostate cancer}

EMT has been known to be involved in a spectrum of physiology and pathology process. Originally EMT is a physiological process in which epithelial cells turn into mesenchymal cells through a specific signaling pathway. Via EMT, epithelial cells lose their epithelial phenotypes such as cell polarity and cell-cell adhesion, and gain mesenchymal characteristics such as high capability of migration, invasion, anti-apoptosis and disorganization of extracellular matrix. Prostate tumors are adenocarcinomas, arising originally from the glandular epithelium of the prostate gland and prostatic ductules. Castration can induce EMT [2], which might be a critical biological process for the malignant tumor cells of epithelial origin

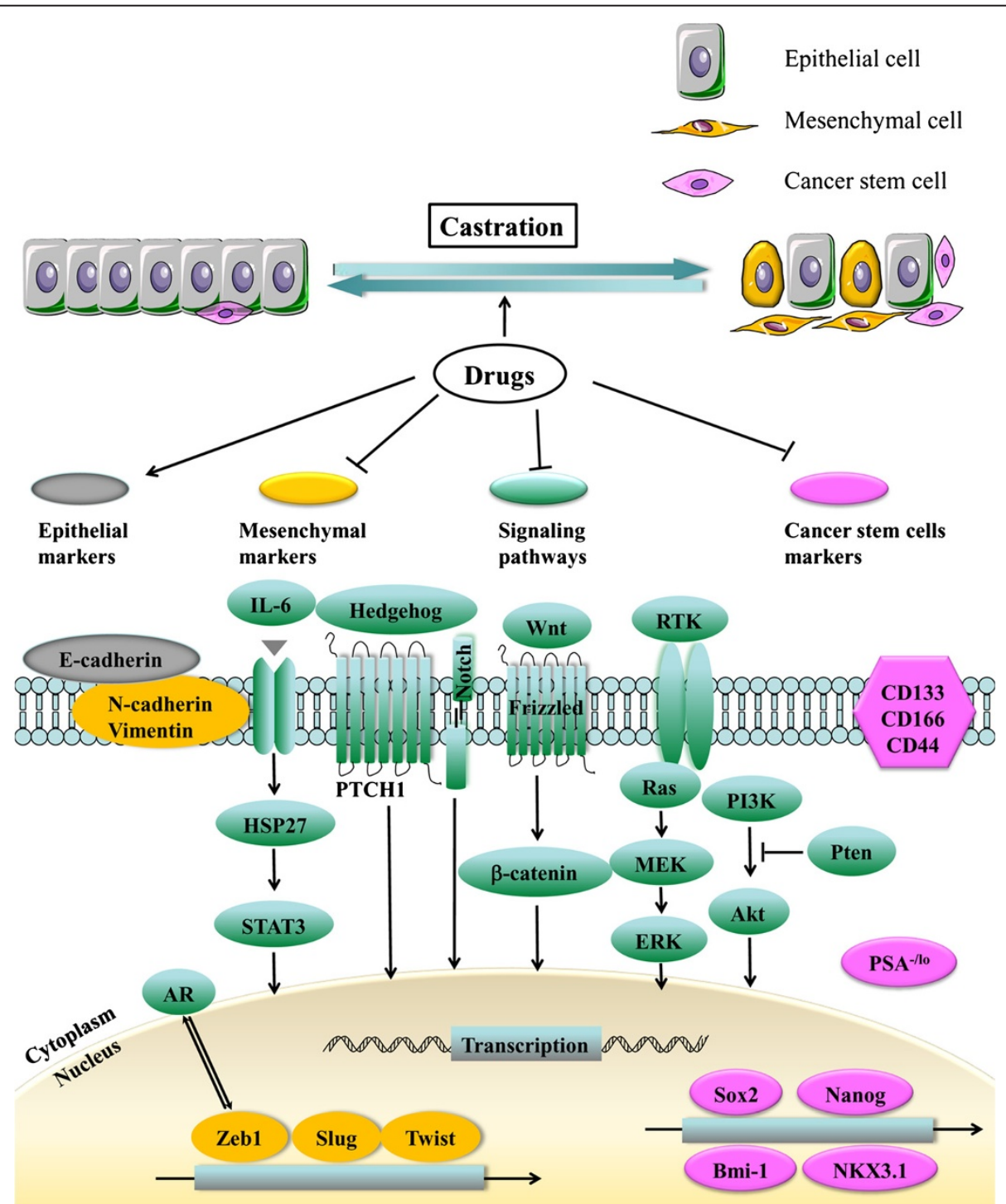

Figure 1 Contribution of EMT, CSC and related signaling to CRPC. Castration induces EMT and enhances the stemness of CSCs, which are the two key contributors for the development of castration resistance. Following castration, epithelial cells lose their epithelial phenotypes, i.e., biomarkers such as E-cadherin, but gain mesenchymal characteristics or biomarkers such as N-cadherin and Zeb-1. Cancer stem cells are stem cell-like tumor cells, which have the capability of self-renewal and differentiation. Castration can enrich this population. Certain molecules might be regarded as prostate cancer stem cell markers, such as CD133, CD166, and etc. Specific signaling including Wnt, Notch, SHH, and others might be the underlying molecular basis of the functions of EMT and CSCs. The EMT appears to be a dynamic process. Development of drugs either inhibiting EMT, CSCS and specific signaling pathways or enhancing expression of epithelial cell markers might be a novel, additional strategy to treat CRPC in the future. $(\rightarrow$, Promote; $\perp$, Inhibit.) 
to leave the epithelium, invade into the stroma area, and disseminate to distal organs, as reported in recent studies [3-5].

Multiple proteins participate in EMT and its reverse process, MET (Mesenchymal-epithelial transition). A variety of biomarkers have been demonstrated for studies on EMT, including E-cadherin, N-cadherin, Vimentin, Snail, Zeb1, Twist and others [6]. Amongst them, E-cadherin locates in the cell surface of epithelial tissues and mediates cell-cell adhesion to bind cells together in the normal epithelial cells. Its expression level is negatively correlated with the occurrence of EMT and tumor invasion. On the contrary, Vimentin (a cytoskeletal marker) and N-cadherin (a cell surface marker) are associated with the initiation of EMT and the progression from well differentiated adenoma to invasive carcinoma. In addition, Snail, Slug, Zeb1, Zeb2 and Twist are able to down-regulate the level of E-cadherin and drive EMT to occur [7].

Sun et al [2] have found that androgen deprivation results in EMT in the prostate cancer. Epithelial marker (e.g. E-cadherin) levels are decreased whereas mesenchymal marker (e.g. N-cadherin, Zeb1, Twist1, and Slug) expression is increased in normal mouse prostate tissue following castration. Similar changes are observed in castrated human LuCaP35 xenograft tumors. They also prove that an EMT occurs in human samples undergoing ADT. During the EMT transition, a mesenchymal marker Zeb1, a transcription factor, mediates the progress by Zeb1-AR feedback loop [2]. The evidence for Zeb1 to be involved in CRPC has also been supported by another group. Graham et al find that Zeb1 is markedly enhanced in prostate cancer cells and insulin-like growth factor-I (IGF-I) is responsible for the overexpression of Zeb1 [8]. Twist, another transcription factor, is highly expressed in prostate cancer and twist expression is strongly associated with Gleason score. Blockade of Twist increases the level of E-cadherin and decreases the capability of invasion and migration of androgen-independent prostate cancer cells $[9,10]$. In addition, Slug, another EMT transcription factor, is regulated by androgen, cooperates with AR and promotes the development of CRPC [11].

Similarly, Reiter and colleagues have found a remarkable increase in $\mathrm{N}$-cadherin expression in CRPC xenografts as well as in both primary and metastatic tumors of patients with CRPC [12]. Application of exogenous $\mathrm{N}$-cadherin could induce EMT, invasion, migration of multiple prostate cancer cell lines in vitro and in vivo. Specific N-cadherin antibody could suppress the process of EMT, decrease tumor growth, invasion and migration, and block the progression to castration-resistance via reducing the activity of AKT and IL- 8 expression. Therefore, this group has identified $\mathrm{N}$-cadherin as a critical cause of prostate cancer metastasis and CRPC. It is proposed that therapies targeting this EMT component with monoclonal antibodies will be a promising approach for further preclinical and clinical validation.

Meanwhile, several EMT biomarkers have been demonstrated to be associated with the development of prostate cancer in the last decade. Loss of E-cadherin or switch of E-cadherin to N-cadherin leads to destruction of cell-cell adhesion, which drives adenoma to become carcinoma [13]. As an osteoblast cadherin, Cadherin-11 could provide association between prostate cancer cells and osteoblasts, enhance the invasion and migration capacities [14]. Zincfinger transcription factor Snail could not only repress the transcription and expression of E-cadherin but also trigger EMT in prostate cancer [15]. Although these molecules have been investigated for prostate cancer in general and not specific for CRPC, they might be potential candidates of EMT markers for CRPC.

In short words, these studies together suggest that EMT and its biomarkers contribute to drug resistance in prostate cancer [16]. E-cadherin, N-cadherin, Zeb1, Twist, Slug, Snail and other EMT markers play important roles in the regulation of the invasive and metastatic potential of prostate cancer cells. Therefore, therapeutic strategies purporting to intervene EMT process or to reverse EMT phenotypes might become alternatives for future cancer therapy.

\section{Cancer stem cells and castration-resistant prostate cancer}

CSCs are proposed to be stem-like cells in tumors, which have the ability to self-renew and to differentiate into new diverse tumor cells. These cells are thought to be a subpopulation of the tumor cells that express specific surface antigens and possess mesenchymal phenotypes, which are important in tumor initiation and progression including castration resistance and metastasis.

As an important mechanism in the de novo theory of CRPC, CSCs are referred to as malignant epithelial stem cells in the lurker cell pathway [1]. Very early, John Isaacs [17] has postulated that initial occurrence of a subpopulation of androgen-independent tumor cells can cause the fail of androgen ablation therapy and the development of CRPC. Denmeade and colleagues [18] reveal that the basal cells of prostate contain a subpopulation of androgen-independent epithelial stem cells. In support of this hypothesis, using a novel human prostate cancer xenograft (LAPC-9), Craft et al [19] have reported that the occurrence of CRPC attributed to clonal expansion of a small percentage of androgen-independent cells. They conclude that prostate cancers contain both androgen sensitive and insensitive cells and selective pressure of ADT alters the relative frequency of these cells, leading to development of CRPC.

CSCs biomarkers are searched and used to identify and isolate CSCs in prostate cancer. Frequently used biomarkers in CRPC related CSCs include Nkx3.1, CD166, 
$\mathrm{PSA}^{-/ \mathrm{LO}}$, Nanog, Bmi-1 and Sox2 (Table 1). Other potential biomarkers contain Lgr4, Sca-1, $\alpha 2 \beta 1$, CD44, $\mathrm{CD} 44^{+} / \alpha 2 \beta 1^{\mathrm{hi}} / \mathrm{CD}_{133^{+}}, \mathrm{CD} 44^{+}$CD24${ }^{-}, \mathrm{p} 63, \mathrm{Lin}^{-} \mathrm{CD} 44^{+}$ CD $133^{+} \mathrm{Sca}-1^{+} \mathrm{CD} 117^{+}$, Trop2, ALDH1 and others (Table 1). The features and related studies for each of the above mentioned markers are listed in Table 1.

Several biomarkers have been identified to be associated with the CSCs in CRPC. For example, Shen and colleagues [20] have found that castration-resistant Nkx3.1-expressing positive cells (CARNs), a subpopulation of luminal epithelial cells, are CSCs in their study of lineage association between normal prostate progenitor cells and cancer cells. Basal cells decrease and luminal cells proliferate in the oncogenic formation. Compared with control Nkx3.1Cre $\mathrm{ERT} 2 /+^{\mathrm{E}}$; Pten ${ }^{+/+}$mice with normal phenotype, Nkx3.1 $1^{\text {CreERT2/+}}$; Pten ${ }^{\text {flox/flox }}$ mice develop high-grade prostatic intraepithelial neoplasia (PIN) and carcinoma following inducible deletion of Pten in the Nkx3.1 population [20]. In addition to the homeobox-containing transcription factor $\mathrm{Nkx3.1}$, some cell surface markers are always available for identifying CSCs in both murine and human prostate tissues. One of the surface markers, CD166, is identified as a potential surface marker for castration resistant tumor cells [21]. The level of CD166 increases in both murine castrated prostate epithelial cells and human CRPC. CD166 ${ }^{\text {hi }}$ population isolated by CD166 marker has higher capacity to form tumor-spheres, compared with $\mathrm{CD} 166^{\text {lo }}$ population. In addition, compared to $\mathrm{TROP} 2{ }^{\text {hi }} \mathrm{CD} 49 \mathrm{f}^{\text {hi }} \mathrm{CD} 166^{\text {lo }}$, $\mathrm{TROP} 2{ }^{\text {hi }} \mathrm{CD} 49 \mathrm{f}^{\text {hi }} \mathrm{CD} 166^{\text {hi }}$ subset detects increased regeneration capacity in vivo. Over-expression of CD166 and CD166 ${ }^{\text {hi }}$ cells is correlated with castration resistance in both Pten deleted mice and human prostate cancer cells [21]. Interestingly, $\mathrm{PSA}^{-/ \mathrm{lo}}$ prostate cancer cells are also demonstrated as an important cell type for CRPC [22]. Compared with $\mathrm{PSA}^{+}$cells, $\mathrm{PSA}^{-/ \mathrm{lo}}$ prostate cancer cells are more clonogenic and tumorigenic. They resist to castration, form holoclones and spheres and develop tumors. PSA ${ }^{-/ \text {lo }}$ prostate cancer cells are enriched following ADT and initiate a new outbreak of tumor development. A decrease in the number of PSA-producing cells is also observed by another group in patients after ADT [23].

Of note, a couple of pluripotent stem cell markers have also been associated with CRPC cells, further raising the possibility that stem cells play critical roles in the progression to a castration-resistant condition. For example, Nanog facilitates the tumor cells to acquire CSCs phenotypes and properties and promotes androgen independence in androgen deprived environment. $\mathrm{LNCaP}$ cells with over-expression of Nanog are easier to agglomerate together to form clones and spheres in vitro and lead to tumor in vivo following castration [24,25]. Similarly, Witte and colleagues have also reported that Bmi-1 mRNA level is enhanced in castrated mice prostate tissues and it maintains the stemness of $\mathrm{p}^{+} 3^{+}$stem cells. Suppression of Bmi-1 slows down the progression of malignant tumors in Pten-deletion prostate cancer model [26]. Moreover, a recent study shows that Sox2 is a critical regulator in self-renewal and tumor progression of human prostate cancer [27]. In addition, Sox 2 could also be suppressed by AR and closely associated with castrationresistant tumor growth [28].

As many researchers believe that CSCs may arise from the gene mutations in normal stem cells, it is important to identify markers for stem cells in normal tissues. In this regard, a couple of stem cell markers are recently identified in normal prostates in addition to the above mentioned biomarkers in CRPC. Gao and colleagues have generated a functional prostate gland from $\mathrm{Lin}^{-} \mathrm{CD} 44^{+} \mathrm{CD} 133^{+} \mathrm{Sca}-1^{+}$ $\mathrm{CD}_{117^{+}}$stem cells [29]. Based on $\alpha 2 \beta 1$, stem cells of human prostate epithelial are identified and isolated by Collins and colleagues [30]. A study from Burger et al indicates that prostate stem cell antigen Sca-1, a cell surface marker, is over-expressed in proximal regions of prostatic ducts. Sca-1 cells purified from the proximal ducts have higher capacity of proliferation [31]. Another recent study shows that Lgr4 regulates both prostate epithelial stem cell differentiation and prostate development [32]. Because the stemness of stem cells is linked to tumorigenesis, the cells expressing stem cell markers may be the origin for cancer. The finding of these stem cell markers in the development of prostate may provide a potential therapeutic target for prostate cancer.

Altogether, CSCs are considered to be a novel theory to elucidate the mechanism of surviving prostatic tumor cells following castration. The biomarkers of CSCs could be potential targets for treatment of castration-resistant tumor cells. In conjunction with ADT, novel therapeutics targeting CSCs, e.g. Nkx3.1 ${ }^{+}, \mathrm{CD} 166^{\text {hi }}$, TROP2 ${ }^{\text {hi }}$ CD $49 \mathrm{f}^{\text {hi }}$ CD166 ${ }^{\text {hi }}$, TRA-1-60/CD151/CD166, PSA ${ }^{-/ l o}$, Nanog, Bmi-1 cells, might be developed to eradicate remaining refractory tumor cells and to prevent recurrence of CRPC.

\section{Possible link between epithelial-to-mesenchymal transition} and cancer stem cells in castration-resistant prostate cancer Numerous studies have shown that EMT and CSCs are primary mechanisms for drug resistance in cancer including CRPC. Recently, a few studies have shown that characteristics of EMT are closely associated with the signatures of CSCs, which could lead to tumor recurrence and drug resistance phenotype.

Mani et al [33] recently find the experimental evidence to connect EMT to the emergence of CSCs in breast cancer. They have demonstrated that after TGF- $\beta$ treatment (a potential inducer of EMT), differentiated mammary epithelial cells give rise to CD $44^{\text {high }} \mathrm{CD} 24^{\text {low }}$ stem-like cells, as is seen in the case of induced by the expression of well-known E-cadherin transcription repressors, such 
Table 1 EMT markers, cancer stem cell markers and signaling pathways involved in EMT and CSC in prostate cancer especially in castration-resistant prostate cancer

\begin{tabular}{|c|c|c|c|}
\hline EMT marker & Function & CRPC & Refs \\
\hline E-cadherin & Regulates the invasive capacity of prostate cancer cells & & {$[3,57,58]$} \\
\hline$\beta$-Catenin & Regulates the process of EMT and metastatic phenotypes & & [59] \\
\hline $\mathrm{N}$-cadherin & Promotes growth, metastasis and castration resistance in prostate cancer & Yes & {$[12,60,61]$} \\
\hline Cadherin-11 & $\begin{array}{l}\text { Enhances migration and invasion capacity of prostate cancer cells, increases } \\
\text { the association with osteoblasts }\end{array}$ & & {$[14,62]$} \\
\hline Vimentin & Promotes prostate cancer cell invasion and metastasis & Yes & [63] \\
\hline Fibronectin & Protects cells from undergoing apoptosis & & {$[64,65]$} \\
\hline Collagen 1 & Have an effect on EMT of prostate cancer cells & & [65] \\
\hline alphall(b)beta3 integrin & Participates in the metastatic progression of prostatic adenocarcinoma & & [66] \\
\hline Syndecan-1 & Associates with Gleason score and tumor progression of prostate cancer & & [67-69] \\
\hline Zeb1 & Altering the invasive phenotype of Prostate cancer cells & Yes & {$[2,8,70]$} \\
\hline Slug & Correlates with advanced pathological grades of prostate cancer & Yes & {$[11,71]$} \\
\hline Snail & Contributes to prostate cancer progression and metastasis & & {$[4,5,72,73]$} \\
\hline Twist & Correlates with Gleason grading and metastasis & Yes & {$[9,10]$} \\
\hline ETS-1 & Mediates by TGF- $\beta$, affects cell growth and tumor formation & Yes & {$[74,75]$} \\
\hline CSC markers & Function & CRPC & Refs \\
\hline Lgr4 & Regulates early prostate development and stem cell differentiation & & [32] \\
\hline a2 $\beta 1$ integrin & Produces prostate-like glands & & [30] \\
\hline CD133 & Functions as a normal prostate stem cell marker and has tumor formation ability & & [76] \\
\hline CD166 & A potential surface marker for castration resistant tumor cells & Yes & [21] \\
\hline PSA & Displays increased colony and sphere-form capacity & Yes & [22] \\
\hline CD44 & Associates with cells of neuro-endocrine phenotype & & [77] \\
\hline $\mathrm{CD} 44^{+} / \mathrm{a} 2 \beta 1^{\mathrm{hi}} / \mathrm{CD} 133^{+}$ & $\begin{array}{l}\text { Presents high proliferative ability in vitro and can differentiate to an } \\
\text { AR-positive phenotype similar to prostate cancers in vivo }\end{array}$ & & [78] \\
\hline CD44+ CD24(-) & Exhibits stem cell characteristics and predicts overall survival in prostate cancer patients. & & [79] \\
\hline Sca-1 & Have high proliferative ability and high capacity to reconstitute prostatic tissue & & [31] \\
\hline Nkx3.1 & Indicates that luminal cells might be a cell of origin & Yes & [20] \\
\hline p63 & $\begin{array}{l}\text { Produces all epithelial lineages of the adult prostate } \\
\text { (i.e., basal, luminal, and neuroendocrine cells) }\end{array}$ & & {$[80,81]$} \\
\hline Lin'SCa-1 $^{-}$CD49f ${ }^{+}($LSC) & Produces prostatic tubule structures & & [82] \\
\hline $\mathrm{Lin}^{-} \mathrm{CD} 44^{+} \mathrm{CD} 133^{+} \mathrm{Sca}-1^{+} \mathrm{CD} 117^{+}$ & Produces a prostate after transplantation in vivo & & [29] \\
\hline Trop2 & Trop2 ${ }^{\text {hi }}$ basal cells give rise to basal, luminal, and neuroendocrine cells in vivo & & [83] \\
\hline $\mathrm{ALDH} 1$ & Associates with a poor prognosis for patients with prostate cancer & & {$[84,85]$} \\
\hline Nanog & $\begin{array}{l}\text { Promotes CSC phenotypes and properties in vitro and in vivo, promotes } \\
\text { Al phenotypes and CRPC regeneration }\end{array}$ & Yes & {$[24,25]$} \\
\hline Bmi-1 & $\begin{array}{l}\text { A key regulator of self-renewal activity, plays central roles in malignant } \\
\text { progression of prostate cancer }\end{array}$ & Yes & [26] \\
\hline Sox2 & Inhibits by AR signaling and play an important role in CRPC & Yes & [28] \\
\hline TRA-1-60, CD151 and CD166 & Exhibits enhanced sphere-forming capacities in vitro and tumor-initiation capacities in vivo & & [86] \\
\hline $\begin{array}{l}\text { Signal pathway involved } \\
\text { CSC and EMT }\end{array}$ & Function & CRPC & Refs \\
\hline$A R$ & A key regulator for the acquisition of EMT phenotypes & Yes & {$[42,45]$} \\
\hline PTEN/AKT & Promotes prostate tumor growth and metastasis & & [87] \\
\hline AKT/GSK-3ß & Participates in TNFa-induced EMT process & & [88] \\
\hline ERK & Has a profound feedback on EGFR signaling & & [89] \\
\hline AKT & Has a great effect on cell migration via induction of the EMT characteristics & & [89] \\
\hline
\end{tabular}


Table 1 EMT markers, cancer stem cell markers and signaling pathways involved in EMT and CSC in prostate cancer, especially in castration-resistant prostate cancer (Continued)

\begin{tabular}{|c|c|c|c|}
\hline TGF- $\beta$ & Associates with malignant progression of prostate cancer by activation of the EMT phenotypes & & {$[90,91]$} \\
\hline CCL2/CCR2-STAT3 & Promotes prostate cancer cell migration/invasion and EMT pathways & Yes & [92] \\
\hline Hsp27-STAT3-Twist & Promotes prostate cancer metastasis, regulates the process of EMT & Yes & [39] \\
\hline PTEN and RAS/MAPK & $\begin{array}{l}\text { Accelerates prostate cancer malignant progression accompanied by } \\
\text { acquisition of EMT phenotypes and stem-cell like properties }\end{array}$ & Yes & {$[37]$} \\
\hline NF-kappaB & $\begin{array}{l}\text { Correlates with EMT in human prostate cancer cells and may be functionally } \\
\text { associated with the stem-like human prostate tumor initiation cells }\end{array}$ & & {$[86,93,94]$} \\
\hline JAK-STAT & Participates in significantly different gene expression in prostate cancer stem cells & & {$[95]$} \\
\hline PDGF-D & Mediates EMT process and regulates cancer cell invasion & & {$[96]$} \\
\hline IGF-1 & Regulates EMT associated migration and invasion via elevated Zeb1 expression & Yes & {$[8]$} \\
\hline FGFR-1 & Leads to an EMT and distant metastasis & & {$[38]$} \\
\hline EGFR & $\begin{array}{l}\text { Presents loss of cell-cell junctions with decreased epithelial markers and } \\
\text { enhanced mesenchymal markers }\end{array}$ & & [89] \\
\hline WNT & Mediates EMT phenotypes and stemness maintenance of prostate cancer cells & Yes & {$[40,97]$} \\
\hline Notch and Hedgehog & Regulates drug resistance and plays important roles in malignant transformation & Yes & {$[98,99]$} \\
\hline Hypoxia-ERß-HIF-1a/NEGF-A & Mediates EMT and have an implication in Gleason grading & & {$[100]$} \\
\hline DAB2IP & $\begin{array}{l}\text { Regulates EMT and prostate cancer metastasis and serves as a target gene } \\
\text { of EZH2 in prostatic epithelium }\end{array}$ & & [101-103] \\
\hline \multirow[t]{2}{*}{ p63/miR205 } & Suppresses cell migration and metastasis & & [104] \\
\hline & Produces changes in Golgi polarization & & \\
\hline
\end{tabular}

as Twist and Snail. Very importantly, a recent elegant study by Weinberg group indicates that Zeb1, a key EMT regulator, is sufficient to switch the cells from a non-cancer stem cell to a cancer stem cell status and is required for the maintenance of the stemness of breast cancer stem cells [34]. Similar phenomenon is observed in pancreatic cancer. ZEB1, a signature of EMT, suppresses miR-200c, miR-203 and miR-128, which inhibit pluripotency genes, such as the Bmi-1, Sox2 and Klf4 genes [35]. These studies have made a link between EMT and CSCs stemness in breast cancer and pancreatic cancer and raise a possibility that EMT and CSCs can contribute either alone or in conjunction with each other to the initiation and progression of various types of cancers, including prostate cancer. As expected, Kong et al [36] further report that PC3 prostate cancer cells which are forced to express PDGF-D display EMT characteristics and show cancer stem-like cell features after over-expression of pluripotency genes, such as the Nanog, Oct4, Sox2, Lin28 and activation of polycomb repressor complex, which is associated with increased clonogenic and prostasphereforming capacity in vitro and tumorigenicity in vivo. During the process, miR-200b and miR-200c play a critical role in linking EMT phenotypes and CSCs signatures. Overexpression of miR-200 family leads to reversed EMT as well as suppressed self-renewal ability by regulating Notch1 and/or Lin28B expression [36]. Sun et al [2] have also presented the evidence that the association between EMT induction and the emergence of prostate CSC-like phenotype following androgen deprivation. By comparison of the gene expression profiles of the prostate tissues from normal mice to castrated mice, a dramatic decrease in E-cadherin expression and an induction of the expression of mesenchymal markers such as N-cadherin, Zeb1, Twist and slug are observed after castration. Microarray gene analysis reveals that several mesenchymal markers, including Vimentin, Zeb1, Zeb2, Twist1, Snail1 and Slug are significantly increased in the $\mathrm{Lin}^{-} \mathrm{CD} 44^{+} \mathrm{CD} 133^{+} \mathrm{Sca}-1^{+} \mathrm{CD} 117^{+}$ stem cells, as compared to those $\mathrm{Lin}^{-} \mathrm{CD} 44^{-} \mathrm{CD} 133^{-} \mathrm{Sca}-1^{-}$ CD117 mouse prostate non-stem cells [2].

Therefore, in addition to the breast and pancreatic tissues, evidence from prostate cancer also indicate that androgen deprivation or other inducers may lead to an EMT phenotype accompanying with the acquisition of stem cell properties. Taken together, modulation of EMT may attenuate the stemness of CSCs.

Signaling pathways involved in epithelial-to-mesenchymal transition and cancer stem cells in castration-resistant prostate cancer

Although EMT and CSC play a pivotal role in the development of CRPC, what mechanisms might be responsible for EMT or CSC-conferred castration resistance are not well understood. One key mechanism is likely related to the AR and AR signaling, a classic pathway leading to CRPC [1]. Besides the AR axis, the activation has also been presumed to be stimulated by some other pathways, such as growthfactor receptor tyrosine kinase (RTK) activated pathways, 
Pten related pathway, signal transducers and activators of transcription 3 (STAT3) related pathway, Wnt, Notch and Hedgehog signaling pathways [37-41].

\section{AR pathways}

The precise role of AR axis in CRPC and prostate cancer metastasis has been well recognized in the last decades. In addition to the commonly known AR amplification and AR mutant, recent studies have found that androgens and the androgen receptor are functionally required in the process of EMT and the maintenance of prostate stem/progenitor cells. To some extent, androgens can induce EMT in PC-3 and LNCaP prostate cancer cells, with reduced epithelial marker expression and increased level of mesenchymal marker. Androgens alone or in combination with TGF- $\beta$ enhance the capacity of prostate cancer cell migration and invasion, with a significant increase in Snail expression. Meanwhile, only low level of AR is required in androgen-induced EMT phenotype alteration [42]. Via a possible AR-Zeb1 bidirectional, negative feedback loop, Sun et al [2] have found that androgen deprivation could lead to EMT in both normal prostate and prostate cancer tissues. In addition, Slug, another EMT transcription factor, could cooperate with AR and promote the development of CRPC [11]. A recent study reveals that mucin 1 (MUC1) C-terminal subunit (MUC1-C) could form a complex with AR, which could not only occupy the PSA promoter but also associate with induction of the EMT modulated by miR135b mediated [43] or ZEB1 mediated mechanism [44]. Moreover, MUC1-C overexpression in androgen sensitive LNCaP cell also increases cell growth following androgen depletion and anti-androgen (such as bicalutamide) treatment, implicating its role in the occurrence of CRPC. Furthermore, the methylation in $\mathrm{CpG}$ islands of AR promoter is likely related to prostate stem/progenitor cells stemness and differentiation. As a result, prostatic epithelial cells, PCSCs and LNCaP progenitor/stem cells present low AR expression due to high DNMT1/3 level and MBD2-AR promoter binding. Moreover, treatment of prostate cancer cells with 5-AZA, a specific DNA methylation inhibitor, results in an inhibition of self-renewal/growth of prostate stem/progenitor cells in vitro and reduces prostate tumorigenicity in vivo [45].

\section{Growth-factor receptor tyrosine kinase (RTK) activated pathways}

Progression of prostate cancer to CRPC is also associated with enhanced expression of growth factors and receptors capable of activating the receptor tyrosine kinase (RTK) pathways. Utilizing the androgen refractory carcinoma of the prostate (ARCaP) cell model, Graham et al investigated the effect of IGF-I on ZEB1 expression. The ARCaPM $(\mathrm{M}=$ mesenchymal $)$ cells show higher expression of ZEB1 than the ARCaPE cells (E=epithelial). IGF-1 treatment up-regulates the mRNA and protein levels of ZEB1 in vitro via activation of the MEK/ERK pathway. Furthermore, treatment of prostate cancer cells with ZEB1 siRNA results in a more epithelial morphology, with increased expression of E-cadherin and decreased $\mathrm{N}$-cadherin, fibronectin expression, and suppresses prostate cancer cell migration and invasion. These results together suggest that IGF-1 is a key regulator of EMT in prostate cancer, which induces cell invasion, metastasis and CRPC [8]. Using an inducible FGFR1 (iFGFR1) prostate mouse model, Acevedo et al have found that iFGFR1 activation by chemical inducers of dimerization (CID) results in prostate adenocarcinoma that is closely associated with EMT, while CID withdrawal causes a full reversion of PIN. iFGFR1-induced prostate cancer presents higher nuclear EMT-associated Sox9 expression and liver and lymph node metastases [38]. As a part of general signaling activities for most growth factor receptors, activation of endogenous c-Ras might be an important mechanism for CRPC. For example, induced RasN17 expression (a dominant negative form of Ras) in C4-2 cell line increases the sensitivity to Casodex (an anti-androgen drug), inhibits cell proliferation in vitro and causes a dramatic regression of C4-2 xenografts after surgical androgen ablation in vivo [46].

\section{Pten related pathways}

Pten loss and the activation of Pten/PI3K/AKT have been well understood in prostate tumorgenesis and its progression to castration resistance, indicating that Pten related pathway may play an important role in CRPC. Higher level of p-MAPK is observed in malignant and CRPC prostate tissues than non-malignant specimens [37]. Using a series of prostate mouse models, Mulholland et al [37] have reported that in contrast to $\mathrm{Pb}-\mathrm{Cre}+\mathrm{PtenL} / \mathrm{L}$ and $\mathrm{Pb}-\mathrm{Cre}+; \mathrm{K}-$ rasL/W, prostate samples from $\mathrm{Pb}-\mathrm{Cre}+$; PtenL/L;K-rasL/W mutants present an EMT phenotype, with increased expression of mesenchymal molecules including Vimentin, Fibronectin, Snail, Twist and Zeb1. Thus, activation of RAS may contribute to the development of EMT in Pten-deletion prostate epithelial cells. As it is mentioned above, recent studies show that EMT is mechanistically associated with the acquisition of cancer stem cells. The Pten;K-ras prostates, which also present a remarkable expansion of $\mathrm{LSC}^{\text {hi }}$ subpopulation, have enhanced sphere-forming ability compared to Pten deletion prostates. Further isolation by FACS show that only

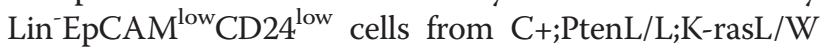
mutants gain mesenchymal properties accompanied by higher sphere-forming capacity. The EpCAM ${ }^{\text {low }} / \mathrm{CD} 24^{\text {low }}$ subpopulation displays mesenchymal cells signatures, with enhanced level of AR and mesenchymal cell markers [37]. Therefore, activation of RAS/MAPK pathway may function as a second hit following changes of the well-known 
PTEN/PI3K/AKT pathway to androgen-insensitive prostate cancer and CRPC [37].

\section{STAT3 related pathway}

Comparing hormone-naive tissue samples with CRPC specimens, Rocchi et al [47] find that molecular chaperone Hsp27 mRNA and protein level are increased after ADT. Over-expression of Hsp27 in LNCaP cells displays highly resistance to anti-androgen reagents in vitro and in vivo. Compared with mock-transfected controls, tumor volume and serum PSA levels are dramatically increased after castration in LNCaP-Hsp27 tumors, suggesting that increased Hsp27 levels can promote the development of CRPC. Furthermore, treatment with Hsp27 antisense oligonucleotides (ASO) or HSP27 shRNA can lead to an inhibited proliferation in LNCaP cells, induce apoptosis via inhibition of STAT3 activity in vitro and reduce the capacity of tumorgenesis after castration in vivo. These results have implied that Hsp27 might be a regulator of STAT3-induced apoptosis in the condition of androgen ablation and be a promising therapeutic target in CRPC [47]. Another report about Hsp27 from their lab indicates that Hsp27 over-expression can regulate EMT in prostate cancer, accompanied by a mesenchymal cell morphology switch. While Hsp27 promotes EMT with enhanced cell migration and invasion ability, silencing Hsp27 could reverse these EMT phenotypes, with reduced STAT3 phosphorylation and its binding to the Twist promoter. These observations suggest that instead of inducing apoptosis, Hsp27 also functions as a key regulator for IL-6-induced EMT via STAT3/Twist signaling pathway [39]. A recent study from Collins and colleagues has explored the contribution of STAT3 signaling pathway to prostate stem/ progenitor cells [48]. Treatment with either specific IL6 antibody or a specific pSTAT3 inhibitor (LLL12), leads to a reduced colony-forming capacity of the stem-like cells from a high-grade clinical prostate cancer sample. Using a murine xenograft model derived from a castration-resistant patient with generally activated STAT3, they found that cells from the xenografts show dramatically decreased tumorigenicity when treated with LLL12. These results suggest that blocking STAT3 might be a novel strategy in the future to suppress tumor initiation capability of human prostate cancer [48].

\section{Wnt pathways}

In addition to the pathways mentioned above, alterations in the Wnt, Notch and Hedgehog pathways have also been reported to contribute to formation of CRPC. Based on $\beta$-catenin immunocytochemical analysis, Wan et al [49] have revealed the functional role of $\mathrm{Wnt} / \beta$-catenin in CRPC. In their study, high levels of $\beta$-catenin is observed in human prostate cancer tissues, which is inversely linked with AR expression, raising the possibility that low or no
AR expression activates $\mathrm{Wnt} / \beta$-catenin signaling. This evidence may explain the phenomenon that only low level of AR lead to androgen-induced EMT phenotype [42]. A recent study reports that Sox 2 promotes EMT via activation of $\mathrm{WNT} / \beta$-catenin, with improved migration and metastasis ability in vitro and in vivo. Over-expression of Sox2 in human breast cell line-MDA231 and human prostate cancer cell line DU145 causes enhanced migration capacity and decreased levels of E-cadherin, DKK3 and increased a-SMA, DVL1 and DVL3. Further experiments indicate that Sox 2 promotes EMT via binding to the promoter of $\beta$-catenin [50]. Additional studies find that the promoter of WIF1 (a WNT inhibitor) is hypermethylated, resulting in its down-regulation in most prostate cancer cell lines [51]. Consistent with the WIF1 over-expression experiments, restoration of WIF1 by treating the cells with 5-Aza induces MET, a reverse process of EMT, with upregulation of epithelial markers (E-cadherin, CK8/18), down-regulation of mesenchymal markers (N-cadherin, Fibronectin, Vimentin, Slug and Twist) and decreased activity of MMP-2/9 in vitro. Meanwhile, over-expression of WIF1 dramatically reduces tumor growth in a xenograft mouse model, accompanied by an increased E-cadherin and CK18 expression and a decreased vimentin level in tumor tissues [51]. Moreover, WNT inhibitors reduce the sphere-forming and self-renewal ability of prostate cancer cells. The opposite results are observed when the cells are treated with WNT3a, with an increased expression of $\beta$-catenin, CK18, CD133 and CD44 [51]. Therefore, WNT signaling affects the functions of CSCs [40].

\section{Notch and hedgehog pathways}

As an important regulator of cell fate determination, Notch signaling is reported to play crucial roles not only in prostate development but also in the progression of prostate cancer. Recent studies have suggested that Notch pathway elements are positively participated in both normal and malignant prostate stem/progenitor cells [52]. Similar to this observation, inactivation of Notch1 dramatically suppresses the clonogenic and prostasphere forming ability, implying that Notch1 is at least partially responsible for maintaining the prostate stem/progenitor cells. Expression of Notch1 is reported to be mediated by miR-200b and miR-200c, which links CSCs signatures with EMT phenotypes. However, further studies are required to unveil whether other Notch pathway elements regulate cancer stem/initiating cell within the prostate [36]. It has been well established that the Hedgehog (Hh) signaling pathway plays central roles in developmental patterning and regeneration of prostate epithelium. Treatment with cyclopamine, a specific inhibitor of the Hh pathway, suppresses tumor growth at $10 \mathrm{mg} / \mathrm{kg}$ and actual regression at $50 \mathrm{mg} / \mathrm{kg}$ in established PC3 and 22RV1 xenograft tumors in vivo [41]. Moreover, cyclopamine suppresses 
transcription of the gene encoding nestin and the Polycomb group protein Bmi-1, two stem cell markers, indicating the role of Hh pathway activity in prostate progenitor cells. Using the castration-regeneration cycle model, Hh signaling pathway blockade by cyclopamine leads to loss of regenerative capacity in rodent ventral prostates. Examination of levels of $\mathrm{Hh}$ pathway targets $\mathrm{PTCH}$ and GLI in metastatic and benign prostate tissues shows that Hh pathway activity is strongly correlated with prostate cancer metastasis, which is attributed to the involvement of EMT [41].

Taken together, these results suggest that all the pathways mentioned above can either function alone or in combination with each other during prostate cancer progression. The advanced CRPC is linked with EMT and/or CSCs, revealing a possible mechanism in the transition of prostate cancer to an androgen-independent state. Drugs designed to target these pathways may provide a promising direction for the future treatment of CRPC.

\section{Regulation of epithelial-to-mesenchymal transition activity, stemness of cancer stem cells and specific signaling pathways in castration-resistant prostate cancer}

After recognizing the importance of EMT, CSCs and related signaling pathways during the development of CRPC, what we should do is to find a way to control these elements by either reversing or inhibiting the activation of these components so to prevent or alleviate CRPC. Studies thus so far suggest that inhibition of any one of these elements or multiple elements together are helpful in alleviation of CRPC.

A promising example is the study on $\mathrm{N}$-cadherin and $\mathrm{N}$-cadherin antibodies. As described above, Reiter and colleagues have reported that $\mathrm{N}$-cadherin could cause metastasis and castration resistance of prostate cancer, but antibodies blocking $\mathrm{N}$-cadherin not only delay the progression of prostate cancer to castration resistance but also inhibit invasion, metastasis and castrationresistant tumor growth in vitro and in vivo [12]. These data warrants that $\mathrm{N}$-cadherin antibodies be validated in preclinical and clinical testing to determine their general toxicity. Therefore, antibodies directly against cell surface markers of EMT and/or CSCs might be a reasonable way to control EMT and CRPC. Another way to control EMT would be to use its related proteins and pathways. OGX-427, which currently in phase II trials by OncoGenex Pharmaceuticals, is another great example. Heat shock protein 27 (Hsp27) induces IL-6 dependent and independent EMT in prostate cancer by promoting phosphorylation and nuclear translocation of STAT3, making STAT3 to bind to the Twist promoter, and activating Twist function. Shut down of Hsp27 reverses EMT and decreases migration, invasion, and matrix metalloproteinase activity of prostate cancer cells. As an anti-sense inhibitor,
OGX-427 suppresses Hsp27 and reduces circulating tumor cells and tumor metastasis [39]. Another group also reports that regulators of EMT have a good effect on several types of cancers (ovarian, nasopharyngeal and esophageal carcinomas), especially in prostate cancer [53]. Chu and colleagues have applied two watersoluble contents of garlic, S-allylcysteine (SAC) and S-allylmercaptocysteine (SAMC), to suppress proliferation and invasion of androgen-independent prostate cancer. The inhibitory effect appears to be due to the reverse of EMT: mesenchymal to epithelial transition (MET). During the reverse transition, E-cadherin is restored and activated whereas Snail expression is decreased in prostate cancer cells [53]. One more evidences of targeting EMT is the study of NPI-0052 by Baritaki and colleagues [54]. They show that the proteasome inhibitor NPI-0052 reverses castration resistance to androgen sensitive via inhibiting EMT in human prostate cancer cell lines. NPI-0052 regulates NF-kB-Snail-RKIP pathway by suppressing NF- $\mathrm{KB}$ inhibition, down-regulating the EMT biomarker Snail, and up-regulating Raf-1 kinase inhibitory protein (RKIP). Snail is a crucial target for reversal of resistance. Further experiments indicate that administration of NPI-0052 leads to inhibit anti-apoptotic gene and metastasis [15,54].

On the other hand, molecules targeting cancer stem cells are investigated. Liu and colleagues have demonstrated miR-34a as a potential therapeutic target against prostate cancer stem cells [55]. CD $44^{+}$prostate cancer cells are purified from xenografts in mice and primary tumors in humans as prostate CSCs. They display enhanced tumor proliferating and metastatic capacities in $\mathrm{CD} 44^{+}$ population. MiR-34a is down-regulated in the CD44 ${ }^{+}$ cells. Up-regulation of miR-34a leads to an inhibition of sphere formation and tumor progression in prostate cancer cells and in $\mathrm{CD} 44^{+}$cell. The study of miR-34a indicates that a critical negative regulator of CSCs could be an attractive therapeutic option in prostate cancer with a cancer origin of stem cells. Similarly, another negative regulator of prostate cancer stem cells is identified by Kroon and colleagues [48]. They demonstrate that pSTAT3 is expressed specially in prostate stem-like and progenitor cells with coexpression of IL-6 receptor gp80. If LLL12, a novel pSTAT3 inhibitor, is applied to prevent STAT3 from phosphorylation, the stemness of prostate cancer cells is inihibited, resulting in significant reduction of cancer cell proliferation in primary cultures from patients with high Gleason grades. Strikingly, blocking pSTAT3 by LLL12 also abolishes the outgrowth of castrated tumors from patients in a mouse xenograft model. In addition, targeting the STAT3 pathway in prostate CSCs might be a promising therapeutic way by another group. Hellsten and colleagues [56] find that ALDH + prostate cancer cells are cancer stem celllike cells as they display the properties of CSCs such as 
self-renew, clonogenicity and tumorigenicity as well as elevated expression of CD44 and integrin $\alpha 2 \beta 1$, two CSCs markers, and pSTAT3. Besides galiellalactone, a direct inhibitor of STAT3 pathway, in the culture medium, suppresses proliferation of ALDH + cells. These findings emphasize that targeting CSCs in prostate cancer is a considerable therapeutic approach.

In addition to directly target EMT and CSC, potential therapies targeting signaling pathways related to EMT and CSC are also investigated. Mulholland and colleagues apply mTOR inhibitor rapamycin and MEK inhibitor PD325901 to target the PI3K/AKT and RAS/MAPK signaling in an in vivo prostate cancer model using a bioluminescence image monitoring method. The combined treatment decreases EMT phenotypes, cell proliferation, and metastasis of the $\mathrm{C}+$;PtenL/L;K-rasL/W; Rosa26-luc sphere cells to the lung or the metastasis produced by stem/progenitor cells purified from $\mathrm{C}+$;PtenL/L;K-rasL/W transgenic mice [37]. It is widely believed that castration enriches stem/progenitor cells in the prostate. Using the castration and androgen replacement prostate regeneration paradigm, Hh pathway blockade by cyclopamine or Hh-neutralizing $5 \mathrm{E} 1$ antibody dramatically attenuates prostate regeneration [41], implying that these Hh pathway inhibitors impede the function of prostate stem cells.

\section{Conclusions}

In summary, castration resistance is a major clinic problem. In addition to the classic AR signaling, recent studies have present a large body of evidence that EMT [57-75], CSCs [76-86] and specific signaling [87-104] play important roles during the development of CRPC. Initial experiments also suggest that there is a link between EMT and CSCs. EMT appears to be a 2-way dynamic process. It is proposed that while EMT may enhance the stemness of CSCS and enhance the CRPC, reversing the EMT or MET may attenuate the stemness of CSCs and alleviate CRPC. Further studies will reveal more molecular mechanisms involved in CRPC. It is also possible that these mechanisms can function either alone or in combination with each other.

Nevertheless, focusing on the axis of EMT, CSCs and specific signaling pathways is a novel, breakthrough thinking in the war against CRPC. Among them, development of antibodies against the surface biomarkers including those EMT markers such as $\mathrm{N}$-cadherin, CSC markers such as CD133, and specific signaling molecule such as HSP27 is the easier approach than targeting the transcription factors or cytoplasmic molecules and might hold promise for a novel therapeutic approach for the treatment of prostate cancer. Clinical trials of molecules in these categories to rule out toxicity and to demonstrate efficacy are required to achieve this goal.

\section{Abbreviations}

AR: Androgen receptor; EMT: Epithelial-to-mesenchymal transition; CSCs: Cancer stem cells; CRPC: Castration-resistant prostate cancer; ADT: Androgen deprivation therapy; MET: Mesenchymal-epithelial transition; PIN: Prostatic intraepithelial neoplasia; PSA: Prostate specific antigen.

\section{Competing interests}

The authors declare that they have no competing interests.

\section{Authors' contributions}

PL wrote the manuscript and prepared the Figure and Table, RY assisted in the preparation and WQG edited and modified the manuscript. All authors read and approved the final manuscript.

\section{Authors' information}

To become an Oncologist, Dr. Ping Li has studied as a doctor at Shanghai Jiao Tong University School of Medicine. Dr. Ru Yang is an Assistant Research Scientist in the Department of Stem Cell Research Center, Renji Hospital, Shanghai Jiao Tong University School of Medicine. Dr. Wei-Qiang Gao serves as a professor and Director of State Key Laboratory of Oncogenes and Related Genes and a professor and Director of Stem Cell Research Center, Renji Hospital, Shanghai Jiao Tong University School of Medicine, Dr. Gao also serves as Chair Professor and Associate Dean of Med-X Research Institute Shanghai Jiao Tong University. Dr. Gao has a long-standing interest in the field of cancer research and developmental neurobiology and published papers as the corresponding or first author in journals including Nature, Cell, Science, PNAS, Cancer Research, Neuron, Nature Neuroscience, Development, etc.

\section{Acknowledgements}

The study is supported by funds from the Chinese Ministry of Science and Technology (2012CB966800 to WQG and RY; 2013 CB945600 to WQG and RY and 2012CB967900), the National Natural Science Foundation of China (81130038 and 81372189 to WQG), Science and Technology Commission of Shanghai Municipality (Pujiang program to WQG), Shanghai Education Committee Key Disciplines and Specialties Foundation (J50208 to WQG), Shanghai Health Bureau Key Disciplines and Specialties Foundation (to WQG), and KC Wong foundation (to WQG). Shanghai Jiao Tong University School of Medicine Doctor Innovation Foundation (BXJ201217 to PL).

Received: 15 November 2013 Accepted: 3 March 2014

Published: 12 March 2014

\section{References}

1. Feldman BJ, Feldman D: The development of androgen-independent prostate cancer. Nat Rev Cancer 2001, 1:34-45.

2. Sun Y, Wang BE, Leong KG, Yue P, Li L, Jhunjhunwala S, Chen D, Seo K, Modrusan Z, Gao WQ, Settleman J, Johnson L: Androgen deprivation causes epithelial-mesenchymal transition in the prostate: implications for androgen-deprivation therapy. Cancer Res 2012, 72:527-536.

3. Perl AK, Wilgenbus P, Dahl U, Semb H, Christofori G: A causal role for E-cadherin in the transition from adenoma to carcinoma. Nature 1998, 392:190-193.

4. Cano A, Perez-Moreno MA, Rodrigo I, Locascio A, Blanco MJ, Del BM, Portillo F, Nieto MA: The transcription factor snail controls epithelial-mesenchymal transitions by repressing E-cadherin expression. Nat Cell Bio/ 2000, 2:76-83.

5. Zhou BP, Deng J, Xia W, Xu J, Li YM, Gunduz M, Hung MC: Dual regulation of Snail by GSK-3beta-mediated phosphorylation in control of epithelial-mesenchymal transition. Nat Cell Biol 2004, 6:931-940.

6. Zeisberg M, Neilson EG: Biomarkers for epithelial-mesenchymal transitions. J Clin Invest 2009, 119:1429-1437.

7. Singh A, Settleman J: EMT, cancer stem cells and drug resistance: an emerging axis of evil in the war on cancer. Oncogene 2010, 29:4741-4751.

8. Graham TR, Zhau HE, Odero-Marah VA, Osunkoya AO, Kimbro KS, Tighiouart M, Liu T, Simons JW, O'Regan RM: Insulin-like growth factor-l-dependent up-regulation of ZEB1 drives epithelial-to-mesenchymal transition in human prostate cancer cells. Cancer Res 2008, 68:2479-2488.

9. Kwok WK, Ling MT, Lee TW, Lau TC, Zhou C, Zhang X, Chua CW, Chan KW, Chan FL, Glackin C, Wong YC, Wang X: Up-regulation of TWIST in prostate cancer and its implication as a therapeutic target. Cancer Res 2005, 65:5153-5162 
10. Qin $Q, X u Y, H e T$, Qin C, Xu J: Normal and disease-related biological functions of Twist1 and underlying molecular mechanisms. Cell Res 2012, 22:90-106.

11. Wu K, Gore C, Yang L, Fazli L, Gleave M, Pong RC, Xiao G, Zhang L, Yun EJ, Tseng SF, Kapur P, He D, Hsieh JT: Slug, a unique androgen-regulated transcription factor, coordinates androgen receptor to facilitate castration resistance in prostate cancer. Mol Endocrinol 2012, 26:1496-1507.

12. Tanaka H, Kono E, Tran CP, Miyazaki H, Yamashiro J, Shimomura T, Fazli L, Wada R, Huang J, Vessella RL, An J, Horvath S, Gleave M, Rettig MB, Wainberg ZA, Reiter RE: Monoclonal antibody targeting of N-cadherin inhibits prostate cancer growth, metastasis and castration resistance. Nat Med 2010, 16:1414-1420.

13. Gravdal K, Halvorsen OJ, Haukaas SA, Akslen LA: A switch from E-cadherin to $\mathrm{N}$-cadherin expression indicates epithelial to mesenchymal transition and is of strong and independent importance for the progress of prostate cancer. Clin Cancer Res 2007, 13:7003-7011.

14. Huang CF, Lira C, Chu K, Bilen MA, Lee YC, Ye X, Kim SM, Ortiz A, Wu FL, Logothetis CJ, Yu-Lee LY, Lin SH: Cadherin-11 increases migration and invasion of prostate cancer cells and enhances their interaction with osteoblasts. Cancer Res 2010, 70:4580-4589.

15. Baritaki S, Yeung K, Palladino M, Berenson J, Bonavida B: Pivotal roles of snail inhibition and RKIP induction by the proteasome inhibitor NPI-0052 in tumor cell chemoimmunosensitization. Cancer Res 2009, 69:8376-8385.

16. Nauseef JT, Henry MD: Epithelial-to-mesenchymal transition in prostate cancer: paradigm or puzzle? Nat Rev Urol 2011, 8:428-439.

17. Isaacs JT: The biology of hormone refractory prostate cancer. Why does it develop? Urol Clin North Am 1999, 26:263-273.

18. Denmeade SR, Lin XS, Isaacs JT: Role of programmed (apoptotic) cell death during the progression and therapy for prostate cancer. Prostate 1996, 28:251-265.

19. Craft N, Chhor C, Tran C, Belldegrun A, DeKernion J, Witte ON, Said J, Reiter $\mathrm{RE}$, Sawyers CL: Evidence for clonal outgrowth of androgen-independent prostate cancer cells from androgen-dependent tumors through a two-step process. Cancer Res 1999, 59:5030-5036.

20. Wang X, Kruithof-de JM, Economides KD, Walker D, Yu H, Halili MV, Hu YP, Price SM, Abate-Shen C, Shen MM: A luminal epithelial stem cell that is a cell of origin for prostate cancer. Nature 2009, 461:495-500.

21. Jiao J, Hindoyan A, Wang S, Tran LM, Goldstein AS, Lawson D, Chen D, Li Y, Guo C, Zhang B, Fazli L, Gleave M, Witte ON, Garraway IP, Wu H: Identification of CD166 as a surface marker for enriching prostate stem/progenitor and cancer initiating cells. PLoS One 2012, 7:e42564

22. Qin J, Liu X, Laffin B, Chen X, Choy G, Jeter CR, Calhoun-Davis T, Li H, Palapattu GS, Pang S, Lin K, Huang J, Ivanov I, Li W, Suraneni MV, Tang DG: The PSA(-/lo) prostate cancer cell population harbors self-renewing long-term tumor-propagating cells that resist castration. Cell Stem Cell 2012, 10:556-569.

23. Ryan CJ, Smith A, Lal P, Satagopan J, Reuter V, Scardino P, Gerald W, Scher HI: Persistent prostate-specific antigen expression after neoadjuvant androgen depletion: an early predictor of relapse or incomplete androgen suppression. Urology 2006, 68:834-839.

24. Jeter CR, Badeaux M, Choy G, Chandra D, Patrawala L, Liu C, Calhoun-Davis T, Zaehres H, Daley GQ, Tang DG: Functional evidence that the self-renewal gene NANOG regulates human tumor development. Stem Cells 2009, 27:993-1005.

25. Jeter CR, Liu B, Liu X, Chen X, Liu C, Calhoun-Davis T, Repass J, Zaehres H, Shen $J$ J, Tang DG: NANOG promotes cancer stem cell characteristics and prostate cancer resistance to androgen deprivation. Oncogene 2011, 30:3833-3845.

26. Lukacs RU, Memarzadeh S, Wu H, Witte ON: Bmi-1 is a crucial regulator of prostate stem cell self-renewal and malignant transformation. Cell Stem Cell 2010, 7:682-693.

27. Rybak AP, Tang D: SOX2 plays a critical role in EGFR-mediated self-renewal of human prostate cancer stem-like cells. Cell Signal 2013, 25:2734-2742.

28. Kregel S, Kiriluk KJ, Rosen AM, Cai Y, Reyes EE, Otto KB, Tom W, Paner GP Szmulewitz RZ, Vander GD: Sox2 is an androgen receptor-repressed gene that promotes castration-resistant prostate cancer. PLOS One 2013, 8:e53701.

29. Leong KG, Wang BE, Johnson L, Gao WQ: Generation of a prostate from a single adult stem cell. Nature 2008, 456:804-808.

30. Collins AT, Habib FK, Maitland NJ, Neal DE: Identification and isolation of human prostate epithelial stem cells based on alpha(2)beta(1)-integrin expression. J Cell Sci 2001, 114:3865-3872.
31. Burger PE, Xiong X, Coetzee S, Salm SN, Moscatelli D, Goto K, Wilson EL: Sca-1 expression identifies stem cells in the proximal region of prostatic ducts with high capacity to reconstitute prostatic tissue. Proc Natl Acad Sci U S A 2005, 102:7180-7185.

32. Luo W, Rodriguez M, Valdez JM, Zhu X, Tan K, Li D, Siwko S, Xin L, Liu M: Lgr4 is a key regulator of prostate development and prostate stem cell differentiation. Stem Cells 2013, 31:2492-2505.

33. Mani SA, Guo W, Liao MJ, Eaton EN, Ayyanan A, Zhou AY, Brooks M, Reinhard F, Zhang CC, Shipitsin M, Campbell LL, Polyak K, Brisken C, Yang J, Weinberg RA: The epithelial-mesenchymal transition generates cells with properties of stem cells. Cell 2008, 133:704-715

34. Chaffer CL, Marjanovic ND, Lee T, Bell G, Kleer CG, Reinhardt F, D'Alessio AC, Young RA, Weinberg RA: Poised Chromatin at the ZEB1 Promoter Enables Breast Cancer Cell Plasticity and Enhances Tumorigenicity. Cell 2013, 154:61-74.

35. Wellner U, Schubert J, Burk UC, Schmalhofer O, Zhu F, Sonntag A, Waldvogel B, Vannier C, Darling D, Zur HA, Brunton VG, Morton J, Sansom O, Schuler J, Stemmler MP, Herzberger C, Hopt U, Keck T, Brabletz S, Brabletz T: The EMT-activator ZEB1 promotes tumorigenicity by repressing stemness-inhibiting microRNAs. Nat Cell Biol 2009, 11:1487-1495.

36. Kong D, Banerjee S, Ahmad A, Li Y, Wang Z, Sethi S, Sarkar FH: Epithelial to mesenchymal transition is mechanistically linked with stem cell signatures in prostate cancer cells. PLoS One 2010, 5:e12445

37. Mulholland DJ, Kobayashi N, Ruscetti M, Zhi A, Tran LM, Huang J, Gleave M, Wu H: Pten loss and RAS/MAPK activation cooperate to promote EMT and metastasis initiated from prostate cancer stem/progenitor cells. Cancer Res 2012, 72:1878-1889.

38. Acevedo VD, Gangula RD, Freeman KW, Li R, Zhang Y, Wang F, Ayala GE, Peterson LE, Ittmann M, Spencer DM: Inducible FGFR-1 activation leads to irreversible prostate adenocarcinoma and an epithelial-to-mesenchymal transition. Cancer Cell 2007, 12:559-571.

39. Shiota M, Bishop JL, Nip KM, Zardan A, Takeuchi A, Cordonnier T, Beraldi E, Bazov J, Fazli L, Chi K, Gleave M, Zoubeidi A: Hsp27 regulates epithelial mesenchymal transition, metastasis, and circulating tumor cells in prostate cancer. Cancer Res 2013, 73:3109-3119.

40. Bisson I, Prowse DM: WNT signaling regulates self-renewal and differentiation of prostate cancer cells with stem cell characteristics. Cell Res 2009, 19:683-697.

41. Karhadkar SS, Bova GS, Abdallah N, Dhara S, Gardner D, Maitra A, Isaacs JT, Berman DM, Beachy PA: Hedgehog signalling in prostate regeneration, neoplasia and metastasis. Nature 2004, 431:707-712.

42. Zhu ML, Kyprianou N: Role of androgens and the androgen receptor in epithelial-mesenchymal transition and invasion of prostate cancer cells. FASEB J 2010, 24:769-777.

43. Rajabi H, Ahmad R, Jin C, Joshi MD, Guha M, Alam M, Kharbanda S, Kufe D: MUC1-C oncoprotein confers androgen-independent growth of human prostate cancer cells. Prostate 2012, 72:1659-1668.

44. Rajabi H, Alam M, Takahashi H, Kharbanda A, Guha M, Ahmad R, Kufe D: MUC1-C oncoprotein activates the ZEB1/miR-200c regulatory loop and epithelial-mesenchymal transition. Oncogene 2013. doi: 10.1038/onc.2013.114.

45. Tian J, Lee SO, Liang L, Luo J, Huang CK, Li L, Niu Y, Chang C: Targeting the unique methylation pattern of androgen receptor (AR) promoter in prostate stem/progenitor cells with 5-aza-2'-deoxycytidine (5-AZA) leads to suppressed prostate tumorigenesis. J Biol Chem 2012, 287:39954-39966.

46. Bakin RE, Gioeli D, Bissonette EA, Weber MJ: Attenuation of Ras signaling restores androgen sensitivity to hormone-refractory C4-2 prostate cancer cells. Cancer Res 2003, 63:1975-1980.

47. Rocchi P, Beraldi E, Ettinger S, Fazli L, Vessella RL, Nelson C, Gleave M: Increased Hsp27 after androgen ablation facilitates androgen-independent progression in prostate cancer via signal transducers and activators of transcription 3-mediated suppression of apoptosis. Cancer Res 2005, 65:11083-11093.

48. Kroon P, Berry PA, Stower MJ, Rodrigues G, Mann VM, Simms M, Bhasin D, Chettiar S, Li C, Li PK, Maitland NJ, Collins AT: JAK-STAT blockade inhibits tumor initiation and clonogenic recovery of prostate cancer stem-like cells. Cancer Res 2013, 73:5288-5298.

49. Wan X, Liu J, Lu JF, Tzelepi V, Yang J, Starbuck MW, Diao L, Wang J, Efstathiou E, Vazquez ES, Troncoso P, Maity SN, Navone NM: Activation of beta-catenin signaling in androgen receptor-negative prostate cancer cells. Clin Cancer Res 2012, 18:726-736.

50. Li X, Xu Y, Chen Y, Chen S, Jia X, Sun T, Liu Y, Li X, Xiang R, Li N: SOX2 promotes tumor metastasis by stimulating epithelial-to-mesenchymal 
transition via regulation of WNT/beta-catenin signal network. Cancer Lett 2013, 336:379-389.

51. Yee DS, Tang Y, Li X, Liu Z, Guo Y, Ghaffar S, McQueen P, Atreya D, Xie J, Simoneau AR, Hoang BH, Zi X: The Wnt inhibitory factor 1 restoration in prostate cancer cells was associated with reduced tumor growth, decreased capacity of cell migration and invasion and a reversal of epithelial to mesenchymal transition. Mol Cancer 2010, 9:162.

52. Leong KG, Gao WQ: The Notch pathway in prostate development and cancer. Differentiation 2008, 76:699-716.

53. Chu Q, Ling MT, Feng H, Cheung HW, Tsao SW, Wang X, Wong YC: A novel anticancer effect of garlic derivatives: inhibition of cancer cell invasion through restoration of E-cadherin expression. Carcinogenesis 2006, 27:2180-2189.

54. Baritaki S, Chapman A, Yeung K, Spandidos DA, Palladino M, Bonavida B: Inhibition of epithelial to mesenchymal transition in metastatic prostate cancer cells by the novel proteasome inhibitor, NPI-0052: pivotal roles of Snail repression and RKIP induction. Oncogene 2009, 28:3573-3585.

55. Liu C, Kelnar K, Liu B, Chen X, Calhoun-Davis T, Li H, Patrawala L, Yan H, Jeter C, Honorio S, Wiggins JF, Bader AG, Fagin R, Brown D, Tang DG: The microRNA miR-34a inhibits prostate cancer stem cells and metastasis by directly repressing CD44. Nat Med 2011, 17:211-215.

56. Hellsten R, Johansson M, Dahlman A, Sterner O, Bjartell A: Galiellalactone inhibits stem cell-like ALDH-positive prostate cancer cells. PLoS One 2011, 6:e22118.

57. Deep G, Gangar SC, Agarwal C, Agarwal R: Role of E-cadherin in antimigratory and antiinvasive efficacy of silibinin in prostate cancer cells. Cancer Prev Res (Phila) 2011, 4:1222-1232

58. Chunthapong J, Seftor EA, Khalkhali-Ellis Z, Seftor RE, Amir S, Lubaroff DM, Heidger PJ, Hendrix MJ: Dual roles of E-cadherin in prostate cancer invasion. J Cell Biochem 2004, 91:649-661.

59. Zhao JH, Luo Y, Jiang YG, He DL, Wu CT: Knockdown of beta-Catenin through shRNA cause a reversal of EMT and metastatic phenotypes induced by HIF-1alpha. Cancer Invest 2011, 29:377-382.

60. Tran NL, Nagle RB, Cress AE, Heimark RL: N-Cadherin expression in human prostate carcinoma cell lines. An epithelial-mesenchymal transformation mediating adhesion withStromal cells. Am J Pathol 1999, 155:787-798.

61. Jennbacken K, Tesan T, Wang W, Gustavsson H, Damber JE, Welen K: $\mathrm{N}$-cadherin increases after androgen deprivation and is associated with metastasis in prostate cancer. Endocr Relat Cancer 2010, 17:469-479.

62. Lee YC, Cheng CJ, Huang M, Bilen MA, Ye X, Navone NM, Chu K, Kao HH, Yu-Lee LY, Wang Z, Lin SH: Androgen depletion up-regulates cadherin-11 expression in prostate cancer. J Pathol 2010, 221:68-76.

63. Singh S, Sadacharan S, Su S, Belldegrun A, Persad S, Singh G: Overexpression of vimentin: role in the invasive phenotype in an androgen-independent model of prostate cancer. Cancer Res 2003, 63:2306-2311.

64. Fornaro M, Plescia J, Chheang S, Tallini G, Zhu YM, King M, Altieri DC, Languino LR: Fibronectin protects prostate cancer cells from tumor necrosis factor-alpha-induced apoptosis via the AKT/survivin pathway. J Biol Chem 2003, 278:50402-50411.

65. Docheva D, Padula D, Schieker M, Clausen-Schaumann H: Effect of collagen I and fibronectin on the adhesion, elasticity and cytoskeletal organization of prostate cancer cells. Biochem Biophys Res Commun 2010, 402:361-366.

66. Trikha M, Raso E, Cai Y, Fazakas Z, Paku S, Porter AT, Timar J, Honn KV: Role of alphall(b)beta3 integrin in prostate cancer metastasis. Prostate 1998, 35:185-192

67. Mennerich D, Vogel A, Klaman I, Dahl E, Lichtner RB, Rosenthal A, Pohlenz HD, Thierauch $\mathrm{KH}$, Sommer A: Shift of syndecan-1 expression from epithelial to stromal cells during progression of solid tumours. Eur J Cancer 2004, 40:1373-1382

68. Contreras HR, Ledezma RA, Vergara J, Cifuentes F, Barra C, Cabello P, Gallegos I, Morales B, Huidobro C, Castellon EA: The expression of syndecan-1 and -2 is associated with Gleason score and epithelial-mesenchymal transition markers, E-cadherin and beta-catenin, in prostate cancer. Urol Oncol 2010, 28:534-540.

69. Shimada K, Nakamura M, De Velasco MA, Tanaka M, Ouji Y, Konishi N: Syndecan-1, a new target molecule involved in progression of androgen-independent prostate cancer. Cancer Sci 2009, 100:1248-1254.

70. Drake JM, Barnes JM, Madsen JM, Domann FE, Stipp CS, Henry MD: ZEB1 coordinately regulates laminin-332 and \{beta\}4 integrin expression altering the invasive phenotype of prostate cancer cells. J Biol Chem 2010, 285:33940-33948.
71. Liu YN, Abou-Kheir W, Yin JJ, Fang L, Hynes P, Casey O, Hu D, Wan Y, Seng $V$, Sheppard-Tillman H, Martin P, Kelly K: Critical and reciprocal regulation of KLF4 and SLUG in transforming growth factor beta-initiated prostate cancer epithelial-mesenchymal transition. Mol Cell Biol 2012, 32:941-953.

72. Neal CL, Mckeithen D, Odero-Marah VA: Snail negatively regulates cell adhesion to extracellular matrix and integrin expression via the MAPK pathway in prostate cancer cells. Cell Adh Migr 2011, 5:249-257.

73. Smith BN, Odero-Marah VA: The role of Snail in prostate cancer. Cell Adh Migr 2012, 6:433-441.

74. Holterman CE, Franovic A, Payette J, Lee S: ETS-1 oncogenic activity mediated by transforming growth factor alpha. Cancer Res 2010, 70:730-740.

75. Kosaka T, Miyajima A, Shirotake S, Kikuchi E, Hasegawa M, Mikami S, Oya M: Ets-1 and hypoxia inducible factor-1alpha inhibition by angiotensin II type-1 receptor blockade in hormone-refractory prostate cancer. Prostate 2010, 70:162-169.

76. Vander GD, Karthaus WL, Dalrymple S, Meeker A, DeMarzo AM, Isaacs JT: The role of CD133 in normal human prostate stem cells and malignant cancer-initiating cells. Cancer Res 2008, 68:9703-9711.

77. Palapattu GS, Wu C, Silvers CR, Martin HB, Williams K, Salamone L, Bushnell T, Huang LS, Yang Q, Huang J: Selective expression of CD44, a putative prostate cancer stem cell marker, in neuroendocrine tumor cells of human prostate cancer. Prostate 2009, 69:787-798.

78. Collins AT, Berry PA, Hyde C, Stower MJ, Maitland NJ: Prospective identification of tumorigenic prostate cancer stem cells. Cancer Res 2005, 65:10946-10951.

79. Hurt EM, Kawasaki BT, Klarmann GJ, Thomas SB, Farrar WL: CD44+ CD24(-) prostate cells are early cancer progenitor/stem cells that provide a model for patients with poor prognosis. Br J Cancer 2008, 98:756-765.

80. Pignon JC, Grisanzio C, Geng Y, Song J, Shivdasani RA, Signoretti S: p63-expressing cells are the stem cells of developing prostate, bladder, and colorectal epithelia. Proc Natl Acad Sci U S A 2013, 110:8105-8110.

81. Xin L, Lukacs RU, Lawson DA, Cheng D, Witte ON: Self-renewal and multilineage differentiation in vitro from murine prostate stem cells. Stem Cells 2007, 25:2760-2769.

82. Lawson DA, Xin L, Lukacs RU, Cheng D, Witte ON: Isolation and functional characterization of murine prostate stem cells. Proc Natl Acad Sci U S A 2007, 104:181-186.

83. Goldstein AS, Lawson DA, Cheng D, Sun W, Garraway IP, Witte ON: Trop2 identifies a subpopulation of murine and human prostate basal cells with stem cell characteristics. Proc Natl Acad Sci U S A 2008, 105:20882-20887.

84. Touma SE, Perner S, Rubin MA, Nanus DM, Gudas し: Retinoid metabolism and ALDH1A2 (RALDH2) expression are altered in the transgenic adenocarcinoma mouse prostate model. Biochem Pharmacol 2009, 78:1127-1138.

85. Li T, Su Y, Mei Y, Leng Q, Leng B, Liu Z, Stass SA, Jiang F: ALDH1A1 is a marker for malignant prostate stem cells and predictor of prostate cancer patients' outcome. Lab Invest 2010, 90:234-244.

86. Rajasekhar VK, Studer L, Gerald W, Socci ND, Scher HI: Tumour-initiating stem-like cells in human prostate cancer exhibit increased NF-kappaB signalling. Nat Commun 2011, 2:162.

87. Conley-Lacomb MK, Saliganan A, Kandagatla P, Chen YQ, Cher ML, Chinni SR: PTEN loss mediated Akt activation promotes prostate tumor growth and metastasis via CXCL12/CXCR4 signaling. Mol Cancer 2013, 12:85.

88. Wang H, Fang R, Wang XF, Zhang F, Chen DY, Zhou B, Wang HS, Cai SH, Du J: Stabilization of Snail through AKT/GSK-3beta signaling pathway is required for TNF-alpha-induced epithelial-mesenchymal transition in prostate cancer PC3 cells. Eur J Pharmacol 2013, 714:48-55.

89. Gan Y, Shi C, Inge L, Hibner M, Balducci J, Huang Y: Differential roles of ERK and Akt pathways in regulation of EGFR-mediated signaling and motility in prostate cancer cells. Oncogene 2010, 29:4947-4958.

90. Pu H, Collazo J, Jones E, Gayheart D, Sakamoto S, Vogt A, Mitchell B, Kyprianou N: Dysfunctional transforming growth factor-beta receptor II accelerates prostate tumorigenesis in the TRAMP mouse model. Cancer Res 2009, 69:7366-7374.

91. Lenferink AE, Cantin C, Nantel A, Wang E, Durocher Y, Banville M, Paul-Roc B, Marcil A, Wilson MR, O'Connor-McCourt MD: Transcriptome profiling of a TGF-beta-induced epithelial-to-mesenchymal transition reveals extracellular clusterin as a target for therapeutic antibodies. Oncogene 2010, 29:831-844.

92. Izumi K, Fang LY, Mizokami A, Namiki M, Li L, Lin WJ, Chang C: Targeting the androgen receptor with siRNA promotes prostate cancer metastasis through enhanced macrophage recruitment via CCL2/CCR2-induced STAT3 activation. EMBO Mol Med 2013, 5:1383-1401. 
93. Zhang Q, Helfand BT, Jang TL, Zhu LJ, Chen L, Yang XJ, Kozlowski J, Smith N, Kundu SD, Yang G, Raji AA, Javonovic B, Pins M, Lindholm P, Guo Y, Catalona WJ, Lee C: Nuclear factor-kappaB-mediated transforming growth factor-beta-induced expression of vimentin is an independent predictor of biochemical recurrence after radical prostatectomy. Clin Cancer Res 2009, 15:3557-3567.

94. Odero-Marah VA, Wang R, Chu G, Zayzafoon M, Xu J, Shi C, Marshall FF, Zhau HE, Chung LW: Receptor activator of NF-kappaB Ligand (RANKL) expression is associated with epithelial to mesenchymal transition in human prostate cancer cells. Cell Res 2008, 18:858-870.

95. Birnie R, Bryce SD, Roome C, Dussupt V, Droop A, Lang SH, Berry PA, Hyde CF, Lewis JL, Stower MJ, Maitland NJ, Collins AT: Gene expression profiling of human prostate cancer stem cells reveals a pro-inflammatory phenotype and the importance of extracellular matrix interactions. Genome Biol 2008, 9:R83.

96. Kong D, Wang Z, Sarkar SH, Li Y, Banerjee S, Saliganan A, Kim HR, Cher ML, Sarkar FH: Platelet-derived growth factor-D overexpression contributes to epithelial-mesenchymal transition of PC3 prostate cancer cells. Stem Cells 2008, 26:1425-1435.

97. Gupta S, lljin K, Sara H, Mpindi JP, Mirtti T, Vainio P, Rantala J, Alanen K, Nees M, Kallioniemi O: FZD4 as a mediator of ERG oncogene-induced WNT signaling and epithelial-to-mesenchymal transition in human prostate cancer cells. Cancer Res 2010, 70:6735-6745.

98. Chang HH, Chen BY, Wu CY, Tsao ZJ, Chen YY, Chang CP, Yang CR, Lin DP: Hedgehog overexpression leads to the formation of prostate cancer stem cells with metastatic property irrespective of androgen receptor expression in the mouse model. J Biomed Sci 2011, 18:6.

99. Domingo-Domenech J, Vidal SJ, Rodriguez-Bravo V, Castillo-Martin M, Quinn SA, Rodriguez-Barrueco R, Bonal DM, Charytonowicz E, Gladoun N, de la Iglesia-Vicente J, Petrylak DP, Benson MC, Silva JM, Cordon-Cardo C: Suppression of acquired docetaxel resistance in prostate cancer through depletion of notch- and hedgehog-dependent tumor-initiating cells. Cancer Cell 2012, 22:373-388.

100. Mak P, Leav I, Pursell B, Bae D, Yang X, Taglienti CA, Gouvin LM, Sharma VM, Mercurio AM: ERbeta impedes prostate cancer EMT by destabilizing HIF-1alpha and inhibiting VEGF-mediated snail nuclear localization: implications for Gleason grading. Cancer Cell 2010, 17:319-332.

101. Chen H, Tu SW, Hsieh JT: Down-regulation of human DAB2IP gene expression mediated by polycomb Ezh2 complex and histone deacetylase in prostate cancer. J Biol Chem 2005, 280:22437-22444.

102. Xie D, Gore C, Liu J, Pong RC, Mason R, Hao G, Long M, Kabbani W, Yu L, Zhang H, Chen H, Sun X, Boothman DA, Min W, Hsieh JT: Role of DAB2IP in modulating epithelial-to-mesenchymal transition and prostate cancer metastasis. Proc Natl Acad Sci U S A 2010, 107:2485-2490.

103. Min J, Zaslavsky A, Fedele G, McLaughlin SK, Reczek EE, De Raedt T, Guney I, Strochlic DE, Macconaill LE, Beroukhim R, Bronson RT, Ryeom S, Hahn WC, Loda M, Cichowski K: An oncogene-tumor suppressor cascade drives metastatic prostate cancer by coordinately activating Ras and nuclear factor-kappaB. Nat Med 2010, 16:286-294

104. Tucci P, Agostini M, Grespi F, Markert EK, Terrinoni A, Vousden KH, Muller PA, Dotsch V, Kehrloesser S, Sayan BS, Giaccone G, Lowe SW, Takahashi N, Vandenabeele P, Knight RA, Levine AJ, Melino G: Loss of p63 and its microRNA-205 target results in enhanced cell migration and metastasis in prostate cancer. Proc Natl Acad Sci U S A 2012, 109:15312-15317.

\section{doi:10.1186/1476-4598-13-55}

Cite this article as: Li et al.: Contributions of epithelial-mesenchymal transition and cancer stem cells to the development of castration resistance of prostate cancer. Molecular Cancer 2014 13:55.

\section{Submit your next manuscript to BioMed Central and take full advantage of:}

- Convenient online submission

- Thorough peer review

- No space constraints or color figure charges

- Immediate publication on acceptance

- Inclusion in PubMed, CAS, Scopus and Google Scholar

- Research which is freely available for redistribution

Submit your manuscript at www.biomedcentral.com/submit
C Biomed Central 